\title{
Profile of hip arthroplasty patients in a teaching hospital
}

\section{Perfil dos pacientes submetidos à artroplastia do quadril em hospital de ensino}

\author{
Vania Regina Goveia ${ }^{1}$; Isabel Yovana Quispe Mendoza'; Braulio Roberto Gonçalves Marinho Couto²; Jose Antonio Guimaräes \\ Ferreira ${ }^{3}$; Edson Barreto Paiva4; Gilberto Lima Guimarães'; Maria Aparecida Resende StoianofF ${ }^{3}$
}

\section{A B S T R A C T}

\begin{abstract}
Objective: to characterize the epidemiological profile of patients undergoing hip replacement, primary or revisional. Methods: we conducted a retrospective, descriptive study, including hip arthroplasties performed from January 2009 to June 2012 in a Belo Horizonte teaching hospital, Minas Gerais State - MG, Brazil. Data were analyzed using descriptive statistics. Results: orthopedic procedures represented $45 \%$ of the operations at the hospital in the period, $1.4 \%$ hip arthroplasties. There were 125 hip replacements, 85 total, 27 partial and 13 reviews. Among the patients, 40\% were male and $60 \%$ were female. Age ranged between 20 and 102 years, mean and median of 73 and 76 years, respectively. The most frequent diagnosis (82\%) was femoral neck fracture by lowenergy trauma caused by falling form standing position. In 13 revision operations, 12 required removal of the prosthesis. The infectious complication led to revision in $54 \%$ of the time, followed by dislocation (15\%), peri-prosthetic fracture (15\%) and aseptic loosening (15\%). The infection etiologic agent was identified in $43 \%$ of occasions. The average length of the prosthesis to a revision operation was eight months. Conclusion: patients undergoing hip arthroplasty are elderly, with femoral neck fracture caused by falling form standing position, affecting more women. The incidence of hip prosthesis loosening was $10 \%$. The main cause of the infection was loosening. The incidence of revisional hip arthroplasty was $10 \%$ and the incidence of hospital mortality in patients undergoing hip arthroplasty was $7.2 \%$.
\end{abstract}

Key words: Orthopedics. Hip Arthroplasty. Reoperation. Surgical Wound Infection.

\section{INTRODUCTION}

C urrently, the use of biomaterials in orthopedic implants is well known. This application has the prospect of becoming more and more intense when considering the high life expectancy of the population in recent decades. Among the obstacles faced in the implementation of these prostheses, there is the rejection of the body to the materials used and infections resulting from surgical procedures. Biocompatibility studies that assess the tolerance of the body to the presence of a foreign body and its toxicity has been made ${ }^{1}$.

Hip arthroplasty represents an advance in surgical procedures of the modern era and, after five decades since the first total hip replacement surgery, the scientific literature data prove the success, between 90 and $95 \%$ for 10 to 15 years, of an operation that relieves pain and corrects deformities ${ }^{2.3}$.

The failure of implants can occur by mechanical or biological reasons. The mechanical ones includes excessive use of the prosthesis, its displacement or misalignment, physical stress and peri-prosthetic bone fracture. The biological failure, on its turn, basically includes inflammation, which can occur as an infectious response or a consequence of the presence of particles in the site. In general and in practice, any of these events requires surgical revision. Infectious complication causes approximately $1.5 \%$ of prosthesis loosening. However, the non-infectious complication is the main cause of surgical revision, for the so-called aseptic prosthesis loosening. In the United States approximately 500,000 arthroplasties take place a year and over 40,000 reviews for aseptic loosening are carried out ${ }^{3-5}$.

Epidemiological studies evaluating the surgical procedures and the performance of implants are important, especially to identify postoperative complications, as well as their causes. The Brazilian Society of Orthopedics and Traumatology (SBOT), similar to what occurs in many countries, proposed a national arthroplasty registry in 2007, when a pilot project was initiated in some Brazilian cities. The partnership with the National Agency of Sanitary Surveillance (ANVISA) was established and soon the national registry will be extended to all health establishments ${ }^{6}$.

1. Nursing School, Universidade Federal de Minas Gerais (EE / UFMG); 2. Institute of Engineering and Technology, Belo Horizonte University Center (EIT / UNIBH); 3. Institute of Biological Sciences, Universidade Federal de Minas Gerais (ICB / UFMG); 4. Risoleta Tolentino Neves Orthopedics Hospital, Universidade Federal de Minas Gerais (HRTN / UFMG). 
Considering the magnitude of the loosening, whether septic or aseptic, of hip joints with regard to increased morbidity, care costs of such complications and also the absence of national data on the subject, it is necessary to produce knowledge that will assess current care practices. Also noteworthy is the contribution to nursing assisting patients in the perioperative period and processing surgical materials.

This study aims to characterize the epidemiological profile of patients undergoing hip arthroplasty.

\section{METHODS}

We conducted a retrospective study, with descriptive approach, for the analysis of hip arthroplasties performed in a public teaching hospital from January 2009 to June 2012. The hospital performs an average of 500 operations per month, $45 \%$ orthopedic and of these, $1.4 \%$ hip arthroplasties. The team of orthopedic surgery consists of 24 surgeons, six of them hip experts, operating weekly and leading all arthroplasties in the institution during the study period.

We used a specific instrument for collecting data through query to the electronic medical records of all patients undergoing hip replacement, primary or revisional, from January 2009 to June 2012. The exclusion criteria were: electronic records unavailable or incomplete filling. The interest collected variables were: gender; age; dates of hospitalization, surgical procedure and outcome (discharge, transfer or death); admission diagnosis, presence of fracture, its cause; the type of surgical treatment (partial, total or revisional arthroplasty); surgeon; type of prosthesis; in the case of surgical revision: time of prosthesis and cause of the review; postoperative complications; and clinical care. We created a database and the variables of interest were analyzed at first, by using descriptive statistics. All incidence rates were calculated using point estimate and 95\% confidence intervals ${ }^{7}$. We applied the Garden classification ${ }^{8}$ to determine the types of fracture

The research project was approved by the Ethics in Research Committee of the Federal University of Minas Gerais - UFMG, Opinion No ETIC 0300.0.203.000-10 and its conduction was authorized by the Teaching, Research and Extension Nucleus of the Risoleta Tolentino Neves Hospital.

\section{RESULTS}

During the period from January 2009 to June 2012 19,233 operations were carried out in the hospital, 8,701 orthopedic, corresponding to $45 \%$ of the procedures. Among these, 125 were hip replacements, which corresponds to $1.4 \%$ of the orthopedic operations.
Among patients undergoing hip arthroplasty, 50 were male (40\%) and 75 (60\%) female. Patient age ranged between 20 and 102 years, mean and median of 73 and 76 years, respectively. The sample of patients had a standard deviation of 14.6 years and $20 \%$ coefficient of variation, which indicates an intermediate variability (Table 1).

Most patients had femoral neck fracture as admission diagnosis, its main cause being the low-energy trauma by falling from standing position Regarding the type of operation, the majority was total hip replacement (68\%). As for the type of prosthesis, in the 27 partial arthroplasties the femoral prosthesis was cemented. Among the 85 total arthroplasties with acetabular and femoral prosthesis, both were cemented on 18 occasions, both were non-cemented on 56 occasions, only the femoral one was cemented in six and only the acetabular was cemented on five. Two orthopedic surgeons were responsible for the absolute majority of the procedures (77\%).

Of the 102 patients with hip fracture diagnosis, 53 had the Garden classification defined: two Garden type II fractures, complete fracture without deviation (4\%), 17 Garden type III, partially varus deviation (32\%) and 34 Garden IV, completely deviation, with displacement of the femoral head (64\%). The two patients with fractures classified as Garden II had symptomatic coxarthrosis prior to the fracture.

Of the 13 surgical revisions, infectious cause was observed in 54\%, requiring prosthesis removal. The surgical site infection was classified as deep, whose etiologic agent was identified in only $43 \%$ of patients (Table 1). Seven other patients underwent reoperation, on three occasions to the repositioning of the prosthesis due to dislocation and four times for surgical cleaning due to superficial infection. In one, culture examination was performed, and the etiologic agent was Staphylococcus aureus.

Also in the 13 reviews the average time of prosthesis to the revision operation was eight months, ranging from 10 days to 48 months. Among the revisions, $38 \%$ occurred within 45 days after arthroplasty. The frequency of prosthesis loosening was observed in 12 patients, with an incidence of $9.6 \%(95 \% \mathrm{Cl}=4.4 \%$ to $14.8 \%)$. The incidence of prosthetic loosening of infectious cause was $5.6 \%(95 \% \mathrm{Cl}=1.6 \%$ to $9.6 \%)$. Of the 125 patients studied, nine died during hospitalization, with a hospital mortality of $7.2 \%(95 \% \mathrm{Cl}=2.7 \%$ to $11.7 \%)$.

\section{DISCUSSION}

Hip arthroplasty is considered a successful surgical procedure for treating diseases that manifest in a more advanced stage of life. In this study, only $12.8 \%$ of patients were younger than 60 years, the majority (63\%) consisting of individuals aged between 70 and 90 years. The elderly population has increased both in developed and developing 
Table 1 - Characteristics of patients undergoing hip arthroplasty between the years of 2009 and 2012.

\begin{tabular}{|c|c|c|c|}
\hline Variable & Categories & Frequency & Percentage \\
\hline \multirow[t]{6}{*}{ Age } & $<60$ anos & 16 & $12,8 \%$ \\
\hline & $60-69$ & 21 & $16,8 \%$ \\
\hline & $70-79$ & 40 & $32,0 \%$ \\
\hline & $80-89$ & 39 & $31,2 \%$ \\
\hline & $90-99$ & 8 & $6,4 \%$ \\
\hline & $>100$ & 1 & $0,8 \%$ \\
\hline \multirow[t]{7}{*}{ Admission diagnosis } & Femoral neck fracture & 102 & $81,6 \%$ \\
\hline & Secondary osteoarthritis & 8 & $6,4 \%$ \\
\hline & Infection & 7 & $5,6 \%$ \\
\hline & Peri-prosthetic fracture & 2 & $1,6 \%$ \\
\hline & Prosthesis dislocation & 2 & $1,6 \%$ \\
\hline & Osteonecrosis & 2 & $1,6 \%$ \\
\hline & Prosthesis aseptic loosening & 2 & $1,6 \%$ \\
\hline Etiology of femoral & Low-energy trauma & 94 & $92 \%$ \\
\hline \multirow[t]{2}{*}{ neck fractures $(n=102)$} & High-energy trauma & 6 & $6 \%$ \\
\hline & Other & 2 & $2 \%$ \\
\hline \multirow[t]{3}{*}{ Surgery type } & Total hip arthroplasty & 85 & $68 \%$ \\
\hline & Partial hip arthroplasty & 27 & $22 \%$ \\
\hline & Revisional arthroplasty & 13 & $10 \%$ \\
\hline \multirow[t]{2}{*}{ Reason for reoperation $(n=7)$} & Superficial infection & 4 & $57 \%$ \\
\hline & Prosthesis dislocation & 3 & $43 \%$ \\
\hline \multirow{4}{*}{$\begin{array}{l}\text { Reason for revisional } \\
\text { operation }(n=13)\end{array}$} & Infection & 7 & $54 \%$ \\
\hline & Peri-prosthetic fracture & 2 & $15 \%$ \\
\hline & Prosthesis dislocation & 2 & $15 \%$ \\
\hline & Prosthesis aseptic loosening & 2 & $15 \%$ \\
\hline \multirow{7}{*}{$\begin{array}{l}\text { Prosthesis removed } \\
\text { after review }(n=13) \\
\text { Identification of the } \\
\text { etiologic agent }(n=7) \\
\text { Etiological agent }(n=3)\end{array}$} & Yes & 12 & $92 \%$ \\
\hline & No & 1 & $8 \%$ \\
\hline & Yes & 3 & $43 \%$ \\
\hline & No & 4 & $57 \%$ \\
\hline & Enterococcus faecalis & 1 & $33 \%$ \\
\hline & Escherichia coli, Proteus mirabilis & 1 & $33 \%$ \\
\hline & Staphylococcus aureus & 1 & $33 \%$ \\
\hline
\end{tabular}

countries. In Brazil, data from the the Brazilian Institute of Geography and Statistics (IBGE) show 23.5 million people over 60 years of age, that is, $12.1 \%$ of the population?

Femoral neck fracture in the elderly affects men and women. In this study, the vast majority of patients undergoing hip arthroplasty had femoral neck fracture and $60 \%$ were women. A study carried out in an orthopedic hospital in the state of Mato Grosso identified the incidence of $11 \%$ of elderly patients with hip fracture, $63 \%$ of them women. Most underwent fracture surgical correction ${ }^{10}$. Another study, conducted in São Paulo, identified the predominance of women among elderly hip fracture victims ${ }^{11}$.

Researchers have conducted investigations to search beyond the incidence and prevalence of falls among the elderly, institutionalized or not, and assess their causes and predisposing factors. A study in Goiania with institutionalized elderly found a prevalence of $38 \%$ in falls ${ }^{12}$.
In Belo Horizonte, among the elderly enrolled in a health center, the prevalence of falls was 59\%, and half fell from standing position ${ }^{13}$. Fall from standing position was also the most common mechanism of injury among elderly patients from the emergency department of the São Paulo Holy Home $^{14}$. In the present study the main cause of hip replacement surgery was femoral neck fracture caused by falling from a standing position, in $92 \%$ of cases.

Infectious and non-infectious complications can cause loosening of the hip prosthesis. In this study, the infection was identified as the leading cause of surgical intervention in $54 \%$ of revisional cases, resulting in prosthesis removal. The literature brings different results, with the infectious complication accounting for $8 \%$ of the revisional cases in a retrospective US study that evaluated more than a thousand records of patients undergoing hip arthroplasty surgical revision. Aseptic loosening is the cause of $51 \%$ of revisions; however, infection has become a major cause of 
prosthesis loss after the surgical intervention for $30 \%$ of patients ${ }^{15}$. Other studies showed similar results ${ }^{16.17}$.

Understanding the interaction between microorganisms, prosthesis and host is necessary to establish the best approach for both diagnosis and treatment of infections associated with the implants. Although infection in hip arthroplasties are not so frequent, when it occurs it has devastating effects, with high morbidity and significant cost. Although the skin colonizing microorganisms are associated with implants infection, their diagnosis is complex and has been studied by many researchers. Conventional culture methods must be combined with other laboratory tests, since studies show negative culture results in $20 \%$ of cases of prostheses infection. In addition, it is estimated that over $10 \%$ present false positive results ${ }^{16-19}$

In this study, microbiological investigation was performed in less than half of the cases of infection by standard clinical methods. Identification of gram-positive bacteria was consistent with the literature, which describes the gram-positive cocci as responsible for approximately $65 \%$ of infections in orthopedic prostheses ${ }^{18}$.

Infections in implants caused by virulent microorganisms, such as $S$. aureus and gram-negative rods, typically manifest themselves as acute infection in the first three months after surgery ${ }^{17,18}$. In this study, almost half of surgical revisions occurred up to three months after hip replacement, and infection was the main cause. It is worth mentioning that reoperations due to infection for surgical cleaning were not effective, requiring surgical revision approach for prosthesis replacement.

Considering the recent developments with regard to the diagnostic investigation of infection associated with orthopedic prostheses, and also to prevention and treatment, despite the hospital has a team of orthopedic surgeons, two heldd the vast majority of procedures, a fact that enables the extensive discussion and review of techniques and procedures related to the perioperative period. People involved in infection control, perioperative nursing and surgeons must work together to discuss best practices to be implemented, as well as reviewing those being applied.
Although this study answered the questions previously established, it has some limitations. The first is the retrospective data collection, from the electronic medical records, which has a variability related to forgetting in recording important details about the patient in the perioperative period. The second limitation is related to the creation of a heterogeneous group that included total and partial arthroplasties, making it impossible to draw meaningful conclusions, only allowing to know the reality of the scenario in question. The partial hip arthroplasty is indicated for more severe patients with worse clinical state, low life expectancy and low functional demand when compared with total arthroplasty. The third limitation is the inclusion of revisions of those undergoing primary arthroplasty in other services.

The concern with improving the quality of care leads us to reflect on strategies to minimize risks and enhance security of the elderly patients undergoing arthroplasty. The results suggest a careful evaluation to assess the risk of falls in hospitalized elderly as a measure to prevent fracture and complications arising from it. An important aspect to be investigated is the adhesion of assistance professionals to infection prevention protocols in arthroplasties, that being the most important complication identified in this study. Considering the aseptic loosening, they have been associated with the presence of endotoxins and its origin may be due to both the excessive use of the prosthesis and the presence of gram negative bacteria. Therefore, investigating the presence of bacteria in surgical instruments that are reprocessed using drinking water becomes essential in order to reset guidelines for reprocessing.

Patients undergoing hip arthroplasty in the study hospital are elderly, with femoral neck fracture caused by falling from standing position, affecting more women than men. The incidence of hip prosthesis loosening was $10 \%$, and infection, $5.6 \%$. The main cause of loosening was infection. The incidence of hip arthroplasty surgical revision was $10 \%$. The hospital mortality in patients undergoing hip arthroplasty was $7.2 \%$.

\title{
R E S U M O
}

\begin{abstract}
Objetivo: caracterizar perfil epidemiológico de pacientes submetidos à artroplastia do quadril, primária ou de revisão. Métodos: estudo retrospectivo, descritivo, incluindo artroplastias do quadril realizadas no período de janeiro/2009 a junho/2012 em hospital de ensino de Belo Horizonte, MG. Os dados foram analisados por estatística descritiva. Resultados: as operações ortopédicas correspondem a 45\% das realizadas no Hospital e 1,4\% à artroplastias do quadril. No período, foram realizadas 125 artroplastias do quadril, sendo 85 totais, 27 parciais e 13 revisões. Dentre os pacientes, 40\% pertenciam ao sexo masculino e 60\%, ao feminino. $A$ idade variou entre 20 e 102 anos, com média e mediana de 73 e 76 anos. O diagnóstico mais frequente (82\%) foi fratura de colo de fêmur por trauma de baixa energia causado por queda da própria altura. Em 13 operações de revisão, 12 necessitaram a remoção da prótese. A complicação infecciosa motivou a revisão em $54 \%$ das ocasiões, seguida de luxação (15\%), fratura periprótese (15\%) e soltura asséptica (15\%). O agente etiológico de infecção foi identificado em $43 \%$ das ocasiões. O tempo médio de prótese até a operação de revisão foi oito meses. Conclusão: os pacientes submetidos à artroplastia do quadril são idosos, com fratura de colo fêmur, causada por queda da própria altura, que acometeu mais as mulheres. A incidência de soltura de prótese do quadril foi 10\%. A principal causa de soltura foi a infecção. A incidência de revisão cirúrgica de artroplastia do quadril foi $10 \%$ e a incidência de mortalidade hospitalar nos pacientes submetidos à artroplastia do quadril foi 7,2\%.
\end{abstract}

Descritores: Ortopedia. Artroplastia de Quadril. Reoperação. Infecção da Ferida Operatória. 


\section{REFERENCES}

1. Mello GMR. Efeito de elementos betagênicos na estabilidade de fases e propriedades de ligas de titânio para implantes ortopédicos [tese]. Campinas/SP: Universidade Estadual de Campinas, Faculdade de Engenharia Mecânica; 2004.

2. Harris WH. The first 50 years of total hip arthroplasty: lessons learned. Clin Orthop Relat Res. 2009;467(1):28-31.

3. Revell PA. The combined role of wear particles, macrophages and lymphocytes in the loosening of total joint prostheses. J R Soc Interface. 2008;5(28):1263-78.

4. Campoccia D, Montanaro L, Arciola CR. The significance of infection related to orthopedic devices and issues of antibiotic resistance. Biomaterials. 2006;27(11):2331-9.

5. Greenfield EM, Bi Y, Ragab AA, Goldberg VM, Nalepka JL, Seabold JM. Does endotoxin contribute to aseptic loosening of orthopedic implants? J Biomed Mater Res B Appl Biomater. 2005;72(1):17985

6. Sociedade Brasileira de Ortopedia e Traumatologia. Radar SBOT: Comissão RNA - novos avanços. Jornal da SBOT 2012; 104:7. Acessado em: 28 jan 2013. Disponível em: http:// www.portalsbot.org.br/public/documents/jornalsbot/ jornalsbot104_71.pdf

7. Altman DG. Practical statistics for medical research. London: Chapman and Hall; 1991

8. Garden RS. The structure and function of the proximal end of the femur. J Bone Joint Surg Br. 1961;43B(3):576-89.

9. Brasil. Secretaria de Direitos Humanos. Secretaria Nacional de Promoção Defesa dos Direitos Humanos. Dados sobre envelhecimento no Brasil. Acessado em: 05 set 2013. Disponível em: http:/ /www.sdh.gov.br/assuntos/pessoa-idosa/dados-estatisticos/ DadossobreoenvelhecimentonoBrasil.pdf

10. Ferreira AC, Almeida DRC, Carrijo FM, Tomazelli R, Romão DF. Incidência e caracterização de idosos na clínica ortopédica por fratura de fêmur, Cáceres MT. Rev Eletr Gestão e Saúde. 2013; $4(2): 53-67$
11. Cunha PTS, Artifon AN, Lima DP, Marques WV, Rahal MA, Ribeiro $\mathrm{RR}$, et al. Fratura de quadril em idosos: tempo de abordagem cirúrgica e sua associação quanto a delirium e infecção. Acta ortop bras. 2008;16(3):173-6.

12. Barbosa AM, Oliveira CL. Prevalência de quedas, fatores de risco e nível de atividade física em idosos institucionalizados. RBCEH. 2012; 9(1):57-70.

13. Chianca TCM, Andrade CR, Albuquerque J, Wenceslau LCC, Tadeu LFR, Macieira TGR, et al. Prevalência de quedas em idosos em um centro de saúde de Belo Horizonte. Rev bras enferm. 2013:66(2):234-40.

14. Parreira JG, Farrath S, Soldá SC, Perlingeiro JAG, Assef JC. Análise comparativa das características do trauma entre idosos com idade superior e inferior a 80 anos. Rev Col Bras Cir. 2013;40(4):26974.

15. Jafari SM, Coyle C, Mortavazi J, Sharkey PF, Parvizi J. Revision hip arthroplasty: infection is the most common cause of failure. Clin Orthop Relat Res. 2010;468(8):2046-51.

16. Parvizi J, Suh DH, Jafari SM, Mullan A, Purtill JJ. Aseptic loosening of total hip arthroplasty: infection always should be ruled out. Clin Orthop Relat Res. 2011;469(5):1401-5.

17. Trampuz A, Widmer AF. Infections associated with orthopedic implants. Curr Opin Infect Dis. 2006;19(4):349-56.

18. Del Pozo JL, Patel R. Clinical practice. Infection associated with prosthetic joints. N Engl J Med. 2009;361(8):787-94

19. Berbari E, Mabry T, Tsaras G, Spangehl M, Erwin PJ, Murad MH, et al. Inflammatory blood laboratory levels as markers of prosthetic joint infection: a systematic review and meta-analysis. J Bone Joint Surg Am. 2010;92(11):2102-9.

Received on 02/04/2014

Accepted for publication 20/06/2014

Conflict of interest: none.

Source of funding: CNPq, protocol $n^{\circ} 473384 / 2010-8$

Address for correspondence:

Vania Regina Goveia

E-mail:vaniagoveia@uol.com.br 